\title{
Comparative study of sustained-release lipid microparticles and solid dispersions containing ibuprofen
}

\author{
Hugo Almeida*, Maria Helena Amaral, Paulo Lobão
}

Pharmaceutical Technology Laboratory, Drug Sciences Department, Faculty of Pharmacy, University of Porto, Portugal

\begin{abstract}
Ibuprofen is one of the most important non-steroidal anti-inflammatory drugs used in the treatment of inflammatory diseases. In its pure state, ibuprofen presents poor physical and mechanical characteristics and its use in solid dosage forms needs the addition of excipients that improve these properties. The selection of the best excipients and the most suitable pharmaceutical dosage form to carry ibuprofen is very important for the industrial success of this drug. Given these factors, lipid microparticles and solid dispersions of ibuprofen with cetyl alcohol, stearic acid, and hydrogenated castor oil were prepared. These formulations were intended to improve the physical and mechanical characteristics and to sustain the release of this drug. Physical mixtures were also prepared with the same ingredients in similar proportions. The solid dispersions of ibuprofen/stearic acid and ibuprofen/hydrogenated castor oil showed the best flow characteristics compared with pure ibuprofen. Further, gelatin capsules filled with lipid microparticles and solid dispersions were submitted to dissolution tests in order to study the influence of the prepared systems in the release profiles of ibuprofen. Prolonged release of ibuprofen was achieved with the lipid microparticles and solid dispersions prepared with the different types of excipients.
\end{abstract}

Uniterms: Ibuprofen/solid dispersions/release profile. Ibuprofen/lipid microparticles/release profile. Excipients. Cetyl alcohol. Stearic acid. Hydrogenated castor oil.

O ibuprofeno é um dos antiinflamatórios não esteróides mais utilizados no tratamento de patologias associadas a processos inflamatórios. Este fármaco, quando no seu estado puro, apresenta características físicas e mecânicas pouco satisfatórias e a sua utilização em formas sólidas só é possível se forem adicionados excipientes que permitam melhorar estas propriedades. A seleção dos excipientes ideais e da forma farmacêutica mais adequada para veicular o ibuprofeno é fundamental para o sucesso industrial deste fármaco. Tendo em conta estes fatores, prepararam-se micropartículas lipídicas e dispersões sólidas de ibuprofeno com cada um dos seguintes excipientes: álcool cetílico, ácido esteárico e óleo de rícino hidrogenado. Estas formulações tinham por finalidade melhorar as características físicas e mecânicas e prolongar a liberação deste fármaco. Foram, também, preparadas misturas físicas do ibuprofeno com os mesmos excipientes e nas mesmas proporções. As dispersões sólidas de ibuprofeno/ácido esteárico e as dispersões sólidas de ibuprofeno/óleo de rícino hidrogenado foram aquelas que apresentaram melhores características de escoamento comparativamente com o ibuprofeno puro. Por outro lado, foram preparadas cápsulas de gelatina com as diferentes micropartículas lipídicas e dispersões sólidas e submetidas a ensaios de dissolução com o objetivo de estudar a influência dos sistemas preparados nos perfis de liberação do ibuprofeno. A liberação prolongada do ibuprofeno foi conseguida nas diferentes micropartículas lipídicas e dispersões sólidas preparadas com os diferentes excipientes.

Unitermos: Ibuprofeno/dispersões sólidas/perfil de liberação. Ibuprofeno/micropartículas lipídicas/perfil de liberação. Excipients. Álcool cetílico. Ácido esteárico. Óleo de rícino hidrogenado.

*Corresponding author: H. Almeida. Laboratório de Tecnologia Farmacêutica, Faculdade de Farmácia, Universidade do Porto. Rua de Jorge Viterbo Ferreira n. ${ }^{\circ} 228,4050-313$ - Porto, Portugal. E-mail: hperas5@hotmail.com 


\section{INTRODUCTION}

Ibuprofen (IB) is a drug of the non-steroidal anti-inflammatory group (NSAIDs), belonging to the sub-group of drugs derived from propionic acid (Oswald, Guimarães, 2001). It is generally well tolerated, but may trigger headaches, stomach pain, vomiting, diarrhea, stomach, and duodenal ulcers (Brunton et al., 2007). Therefore, there is a need to minimize these adverse effects and to prolong its anti-inflammatory action.

There are two key strategies to alter the release and subsequent absorption of drugs: one is based on modification of the drug, and the other is based on modification of the dosage form (Lachman, 2001).

The preparation of solid dispersions is a strategy to change the release and subsequent drug absorption (Chiou, Riegelman, 1971a). The drug is well dispersed in a matrix of a material that modifies its release, encapsulated in the form of particles or compressed to form tablets. For the same purpose, lipid microparticles were prepared using the emulsion/chilling method.

The matrix systems are classified according to their chemical nature and release mechanism. Hydrophilic matrices absorb water and form a gel prior to dissolution (e.g., methylcellulose, agar-agar, alginates, and carbomer) and hydrophobic matrices produce porous solid structures in which the drug is dispersed. Hydrophobic matrices include the inert matrices, which are insoluble in gastric juices (e.g., cellulose acetate, ethyl cellulose, etc.), and lipid matrices that undergo erosion, gastric enzyme lipolysis, or solubilization by ionization (e.g., hydrogenated castor oil, stearic acid, and cetyl alcohol). The choice of matrix is very important, because this choice will influence the ability of the formulation to control the drug release and thereby sustain the therapeutic action over time (Liberal, 2008; Salomen, 1980). Waxes and other related lipidic materials such as cetyl alcohol, stearic acid, and hydrogenated castor oil form matrices that control the release of drugs by diffusion through pores or by erosion (Rowe et al., 2003).

\section{Solid dispersions}

The term "solid dispersion" describes the dispersion of one or more active substances in a carrier or inert solid matrix prepared by melting, using solvents, or by a solvent-melting method (Chiou, Riegelman, 1971b).

Solid dispersions may have several advantages and pharmaceutical applications, including: the uniform and homogeneous distribution of small quantities of drug in the solid state; the stabilization of unstable drugs; the dispersion of liquid or gaseous compounds; and the production of prolonged release systems or the increase of drug dissolution rates.

The combination of a slightly soluble drug in water with a water-soluble matrix results in a rapid-release drug formulation (e.g., solid dispersion of ibuprofen/PEG 4000 or ibuprofen/PEG 8000), can be used to increase the dissolution rate of the drug (Newa, 2008). Another example is the solid dispersion of ibuprofen in Poloxamer 407 in order to increase the solubility and consequently the dissolution rate of the drug (Newa, 2008). Moreover, the combination of a water-soluble drug with a slightly water-soluble matrix sustains the drug release from the matrix. The characteristics of drug release can be altered by changing the ratio between the drug and excipient (Ford, Rubinstein, 1978).

To disperse a drug in an excipient, several methods can be used, including the solvent method (Ford, 1986), the fusion method (Sharma, Joshi, 2007; Yi et al., 2008), the solvent-melting method, as well as freeze- and spraydrying technology (Park et al., 2009).

\section{Lipid microparticles}

Microparticles, as seen in solid dispersions, arise from the need to overcome possible adverse effects and to increase the short half-life of some drugs. The main advantages are the fact that they present a great biocompatibility, low toxicity, high stability, and improve efficacy, absorption, and bioavailability. They can also facilitate the administration, masking the organoleptic properties and protecting the drug (Kumar, 2000).

The microparticles have dimensions that can vary between $1 \mu \mathrm{m}$ and $1000 \mu \mathrm{m}$; however, some authors have considered particles larger than $1 \mathrm{~mm}$ as microparticles.

The microparticles can be classified as reservoirs or matrices. In the first case, the drug is at the core and is surrounded by a layer or film coating, which can be semipermeable or completely permeable. In the second case, the drug is homogeneously dispersed in a matrix of irregular geometry and that is sometimes porous. The drug can be found on the surface of the matrix in direct contact with the external environment. There are several methodologies for the production of microparticles reflecting the physicochemical properties of the drug in order to maintain their unique therapeutic properties. However, there are other factors to take into account such as: the environmental impact of the process; ease of implementation; availability of equipment and resources; cost; and process efficiency. The methods for the production of lipid microparticles include: spray-drying technology (Mahajan, Gattani, 2009); double-emulsion solvent evaporation (Freitas et al., 2005); 
emulsion/chilling, the solvent method (Soppimath, 2001); the engineering division, fluid supercritical (Kang et al., 2008); atomization and modified atomization; fluidized bed (Gouin, 2004); and extrusion.

\section{MATERIAL AND METHODS}

\section{Material}

Ibuprofen (Lot No. 0507939, Roig Farma, Spain), cetyl alcohol (Lanette 16) (Lot No. S383040010, José M. Vaz Pereira SA, Portugal), stearic acid (Lot No. 062,821, Acofarma, Spain), hydrogenated castor oil (Cutina $\mathrm{HR}^{\circledR}$ ) (Lot No. CG42720170, José M. Vaz Pereira SA, Portugal), monosodium phosphate (Lot No. 0194, José M. Vaz Pereira, SA, Portugal), disodium phosphate anhydrous (Lot No. 130470JR, José M. Vaz Pereira, SA, Portugal), propylene glycol (Lot No. VF251920D4, José M. Vaz Pereira, SA, Portugal) and chloroform (Lot No. 7B128128C, Pronolab, José M. Vaz Pereira, SA, Portugal). Gelatin capsules No. 0 (Lot No. 9328900023, Guinama, Spain).

\section{Methods}

\section{Preparation of solid dispersions containing ibuprofen}

Solid dispersions at a 1:2 ratio of ibuprofen/excipient were prepared using the fusion method. This ratio was used to make certain that the excipient contained the ibuprofen, in order to obtain the sustained release of the ibuprofen.

Excipient melting (variable temperature according to the melting point of the excipients) on a hot plate under stirring was used, followed by addition of ibuprofen to the excipient cast, slow cooling for solidification of the mass, and grinding.

Gelatin capsules No. 0 were filled with these solid dispersions (method - capsule filling plate).

\section{Preparation of lipid microparticles containing ibuprofen}

Lipid microparticles of 1:2 ibuprofen/excipient ratio were prepared using the emulsion/chilling method. Excipients were melted (variable temperature according to the melting point of the excipients) on a hot plate under stirring at $600 \mathrm{rpm}$ (in order to achieve particles with micrometric size) and ibuprofen was added to the molten excipient. The oil phase was slowly added to a $1.5 \%(\mathrm{w} / \mathrm{w})$ Tween ${ }^{\circledR} 80$ solution at the same temperature, followed by the quick addition of a mixture of water:propylene glycol $(75: 25)$ at $0{ }^{\circ} \mathrm{C}$, maintaining the agitation at $600 \mathrm{rpm}$. The microparticles obtained were filtered and washed with water. Gelatin capsules No. 0 were filled with these lipid microparticles (method - capsule filling plate).

\section{Preparation of physical mixtures containing ibuprofen}

Physical mixtures of 1:2 ibuprofen/excipient were also prepared, using a Turbula WAB T2F (Switzerland) for 15 minutes.

\section{Determination of particle size-distribution}

The test was performed in the Retsh AS 200 Digit (Germany), for the dry sieving. Sieves with the following mesh diameter were chosen: $1000 \mu \mathrm{m}, 500 \mu \mathrm{m}, 355 \mu \mathrm{m}$, $180 \mu \mathrm{m}, 125 \mu \mathrm{m}$, and $90 \mu \mathrm{m}$. Samples were weighed (50 g) and submitted to a $2.0 \mathrm{~mm}$ amplitude vibration, for two cycles of 5 minutes. Tests were performed in triplicate, and the results shown are the average of the obtained values.

\section{Determination of flow rate and repose angle}

For these tests, a Granulate Flow Tester, Erweka Type: GT / GTB (Germany) was used. A funnel with a metal tip with a hole of $15 \mathrm{~mm}$ and $50 \mathrm{~g}$ of solid dispersions or lipid microparticles were used. The tests were performed in triplicate, with the results shown being the average of the obtained values.

\section{Determination of ibuprofen content using UV-VIS spectrophotometry}

For the determination of ibuprofen content in solid dispersions and lipid microparticles, $75 \mathrm{mg}$ of each sample was dissolved in chloroform $(50 \mathrm{~mL})$ and analyzed by UV-VIS spectrophotometry (UV-VIS spectrophotometer JASCO V-650, Japan) at $272 \mathrm{~nm}$. The accuracy, repeatability, specificity, and linearity of the spectrophotometric method were previously evaluated.

\section{Mass uniformity of capsules}

Mass uniformity test of gelatin capsules filled with the solid dispersions and lipid microparticles was performed. Twenty individually weighed units of capsules containing solid dispersions or lipid microparticles were taken at random and the average mass was determined.

\section{In vitro dissolution test}

For this study, gelatin capsules containing solid dispersions or lipid microparticles and capsules containing only pure ibuprofen were used.

Dissolution tests were performed under the following conditions:

Dissolution apparatus - SOTAX AT7 (Switzerland);

Basket method;

Agitation speed - $100 \mathrm{rpm}$;

Temperature $-37.0 \pm 0.5^{\circ} \mathrm{C}$; 
Dissolution liquid - pH 7.4 phosphate buffer solution (Portuguese Pharmacopoeia VIII);

Dissolution liquid volume - $500 \mathrm{~mL}$;

Sample bulk - $10.0 \mathrm{~mL}$;

Collection times - 30, 60, 120, 240, 360, 600 minutes.

Samples were assayed in triplicate in a UV-VIS spectrophotometer at $272 \mathrm{~nm}$, using $\mathrm{pH} 7.4$ buffer phosphate solution as a blank.

\section{RESULTS AND DISCUSSION}

\section{Determination of particle size-distribution}

Figure I show the particle size-distribution of the different solid dispersions. Solid dispersions of ibuprofen in hydrogenated castor oil and stearic acid presented a higher percentage of particles with average size $>1000 \mu \mathrm{m}$. The solid dispersion of ibuprofen in cetyl alcohol showed a higher percentage of particles between 500 and $1000 \mu \mathrm{m}$.

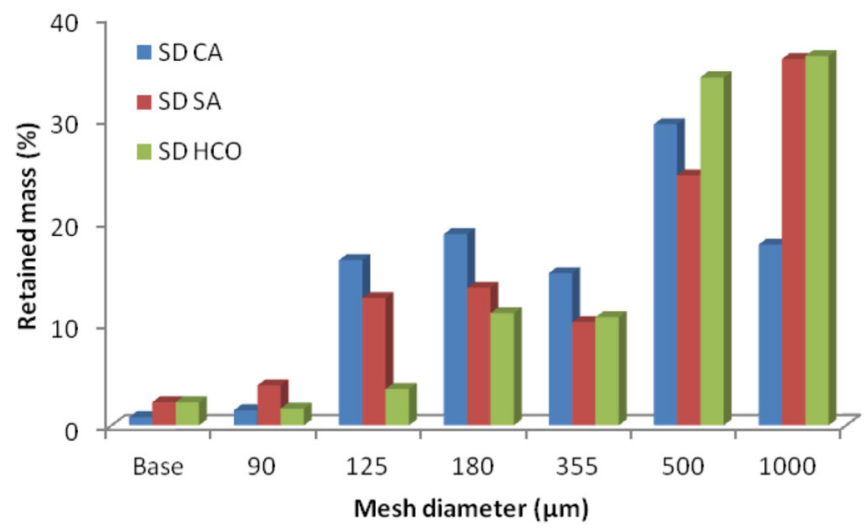

FIGURE 1 - Size distribution of the solid dispersions of ibuprofen (SD CA- solid dispersions of cetyl alcohol; SD SA solid dispersions of stearic acid; SD HCO - solid dispersions of hydrogenated castor oil).

Figure 2 shows the particle size-distribution of the different lipid microparticles. The lipid microparticles of ibuprofen in hydrogenated castor oil and stearic acid presented a higher percentage of particles with average size $>1000 \mu \mathrm{m}$. The microparticles of cetyl alcohol showed a more heterogeneous size distribution.

\section{Determination of flow rate and repose angle}

The pure ibuprofen power did not flow. Similarly, physical mixtures of ibuprofen with each excipient did not flow. In all cases, the particles of the physical mixtures stayed stuck to the funnel wall.

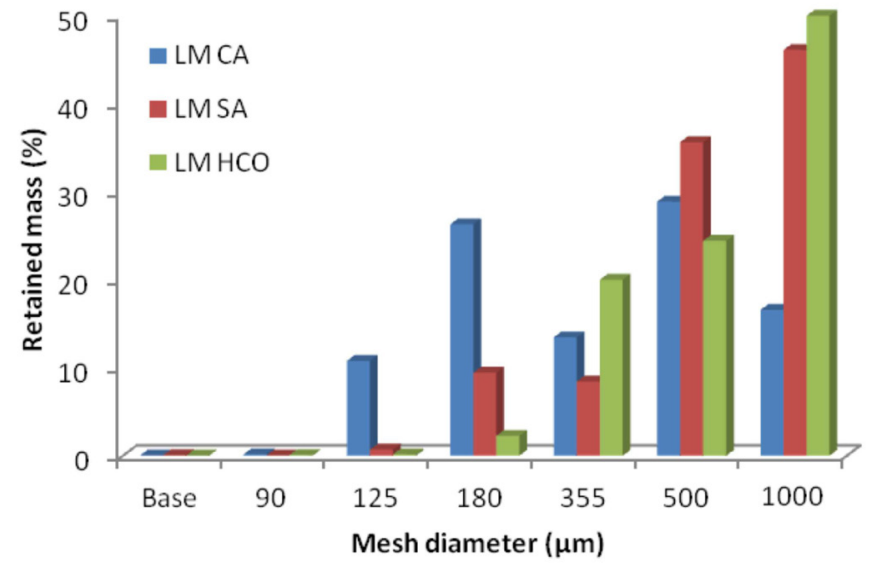

FIGURE 2 - Size distribution of the lipid microparticles of ibuprofen (LM CA- lipid microparticles of cetyl alcohol; LM SA - lipid microparticles of stearic acid; LM HCO - lipid microparticles of hydrogenated castor oil).

The solid dispersion of ibuprofen in cetyl alcohol (SD CA) did not show flowability.

On the other hand, the solid dispersion of ibuprofen in stearic acid (SD SA) showed a flowability of $6.0 \pm 0.28 \mathrm{~s}$ and a repose angle of $44.5^{\circ} \pm 0.31$. The solid dispersion of ibuprofen in hydrogenated castor oil (SD HCO) presented a flowability of $5.3 \pm 0.06 \mathrm{~s}$ and a repose angle of $41.9^{\circ} \pm$ 1.22. The higher percentage of smaller particles presented by cetyl alcohol solid dispersions and also the adhesive forces and/or binding between particles had influence on its lack of flowability.

None of the lipid microparticles formulated with different excipients presented flow characteristics.

\section{Determination of ibuprofen using UV-VIS spectrophotometry}

For ibuprofen UV-VIS spectrophotometry determination, several validation parameters were evaluated. The method showed specificity, good linearity (coefficient of determination of 0.999$)$, accuracy $(101.30 \% \pm 2.55)$, and repeatability $(\mathrm{CV}=0.34 \%)$ within the range of concentrations assayed.

Table I presents the content of ibuprofen in the solid dispersions prepared with the different types of excipients, i.e., cetyl alcohol, stearic acid, and hydrogenated castor oil.

The results of the determination of ibuprofen content in the different solid dispersions showed percentages of drug around $100 \%$ in all cases.

Table II presents the content of ibuprofen in the lipid microparticles prepared with the different types of excipients, i.e., cetyl alcohol, stearic acid, and hydrogenated castor oil. 
TABLE I - Ibuprofen content in solid dispersions

\begin{tabular}{lc}
\hline Solid dispersions & \% of ibuprofen \\
\hline SD CA & 101.95 \\
SD SA & 103.72 \\
SD HCO & 98.31 \\
\hline
\end{tabular}

(SD CA- solid dispersions of cetyl alcohol; SD SA - solid dispersions of stearic acid; SD HCO - solid dispersions of hydrogenated castor oil).

TABLE II - Ibuprofen content in lipid microparticles

\begin{tabular}{lc}
\hline Lipid microparticles & \% of ibuprofen \\
\hline LM CA & 92.12 \\
LM SA & 81.87 \\
LM HCO & 67.56 \\
\hline
\end{tabular}

(LM CA- lipid microparticles of cetyl alcohol; LM SA - lipid microparticles of stearic acid; LM HCO - lipid microparticles of hydrogenated castor oil).

The results of the determination of ibuprofen content in the different lipid microparticles showed different percentages of drug. Lipid microparticles of stearic acid and hydrogenated castor oil showed a percentage of ibuprofen below $90 \%$.

\section{Mass uniformity of capsules}

Table III shows the values of mass uniformity of gelatin capsules prepared with the different solid dispersions.
As can be seen in Table III, the mass of capsules was within the limits of Portuguese Pharmacopoeia VIII.

Table IV show the values of mass uniformity of gelatin capsules filled with the different lipid microparticles.

From the analysis of the results for uniformity of mass it can be seen that only the masses of capsules containing IB or LM CA (lipid microparticles of cethyl alcohol) remained within the limits specified by the Portuguese Pharmacopoeia.

\section{In vitro dissolution test}

After the characterization of capsules, in vitro dissolution studies were performed. Validation parameters of the method for ibuprofen determination (UV-VIS spectrophotometry) were evaluated. The method showed specificity, good linearity (coefficient of determination of 0.9994$)$, accuracy $(100.43 \% \pm 1.97)$, and repeatability $(\mathrm{CV}=0.18 \%)$ within the range of concentrations studied.

Figure 3 shows the dissolution profiles of pure ibuprofen and solid dispersions of this drug in cetyl alcohol, stearic acid, or hydrogenated castor oil contained in gelatin capsules.

As can be seen in Figure 3, due to its crystalline structure, about $95 \%$ of pure ibuprofen was dissolved in the first 30 minutes of the dissolution test. Due to the water-in-oil emulsion properties of cetyl alcohol, solid dispersions of this excipient showed a higher percentage of ibuprofen released (62.8\%) after 30 minutes, followed by solid dispersions of stearic acid (48.1\%), and solid dispersion of hydrogenated castor oil (41.0\%). After

TABLE III - Results of mass uniformity of capsules prepared with ibuprofen and the different solid dispersions

\begin{tabular}{lccccc}
\hline Capsules & Average $(\mathrm{mg})$ & Maximum & Minimum & SD & CV (\%) \\
\hline IB & 415.52 & 398.43 & 437.72 & 11.82 & 2.85 \\
SD CA & 399.08 & 376.58 & 419.60 & 12.21 & 3.06 \\
SD SA & 415.25 & 401.57 & 428.23 & 5.59 & 1.35 \\
SD HCO & 435.64 & 411.65 & 453.88 & 9.04 & 2.07 \\
\hline
\end{tabular}

(IB - Ibuprofen; SD CA- solid dispersions of cetyl alcohol; SD SA - solid dispersions of stearic acid; SD HCO - solid dispersions of hydrogenated castor oil).

TABLE IV - Results of mass uniformity of capsules filled with ibuprofen and the different lipid microparticles

\begin{tabular}{lccccc}
\hline Capsules & Average $(\mathrm{mg})$ & Maximum & Minimum & SD & CV (\%) \\
\hline IB & 415.52 & 398.43 & 437.72 & 11.82 & 2.85 \\
LM CA & 340.85 & 320.98 & 358.45 & 11.25 & 3.30 \\
LM SA & 393.52 & 361.71 & 414.65 & 15.98 & 4.06 \\
LM HCO & 340.16 & 306.48 & 366.20 & 18.67 & 5.49 \\
\hline
\end{tabular}

(IB - Ibuprofen; LM CA- lipid microparticles of cetyl alcohol; LM SA - lipid microparticles of stearic acid; LM HCO - lipid microparticles of hydrogenated castor oil). 


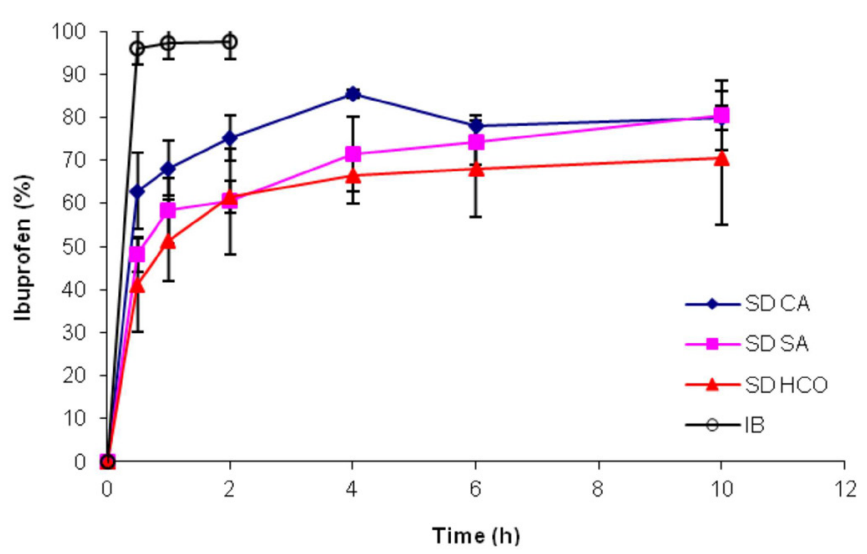

FIGURE 3 - Dissolution profiles of solid dispersions of ibuprofen with different excipients (IB - Ibuprofen; SD CAsolid dispersions of cetyl alcohol; SD SA - solid dispersions of stearic acid; SD HCO - solid dispersions of hydrogenated castor oil).

10 hours of testing, the amount of ibuprofen released from the solid dispersions of cetyl alcohol and stearic acid was almost identical (80\%), while the solid dispersion of hydrogenated castor oil released $70.5 \%$ of drug. However, the solid dispersion of hydrogenated castor oil showed a dissolution profile similar to the solid dispersion of stearic acid (Similarity factor $=58.7$ ) (Prista et al., 1996). Comparing the solid dispersion of cetyl alcohol (SD CA) and the solid dispersion of hydrogenated castor oil (SD HCO), it can be concluded that these two types of solid dispersion presented different profiles (Similarity factor $=40.0)$ (Prista et al., 1996).

Figure 4 shows the dissolution profiles of pure ibuprofen and lipid microparticles of the drug in cetyl alcohol, stearic acid, and hydrogenated castor oil contained in gelatin capsules.

As observed in solid dispersions, and due to the emulsifying properties of cetyl alcohol, lipid microparticles of this excipient have a greater release of drug during the first 30 minutes of testing. These microparticles released $81.4 \%$ of drug within 30 minutes. However the lipid microparticles of stearic acid and hydrogenated castor oil released only about $40 \%$ of ibuprofen.

The lipid microparticles of cetyl alcohol after 10 hours of testing had a percentage of $97.7 \%$ of drug released and the lipid microparticles of stearic acid released $94.5 \%$ of the drug.

Regarding the lipid microparticles of hydrogenated castor oil, they showed only $59.6 \%$ of drug dissolved after 10 hours of testing. The microparticles of cetyl alcohol had a dissolution profile different of the microparticles of stearic acid $\left(f_{2}=33.4\right)$ and hydrogenated castor oil $\left(f_{2}=22.6\right)$.

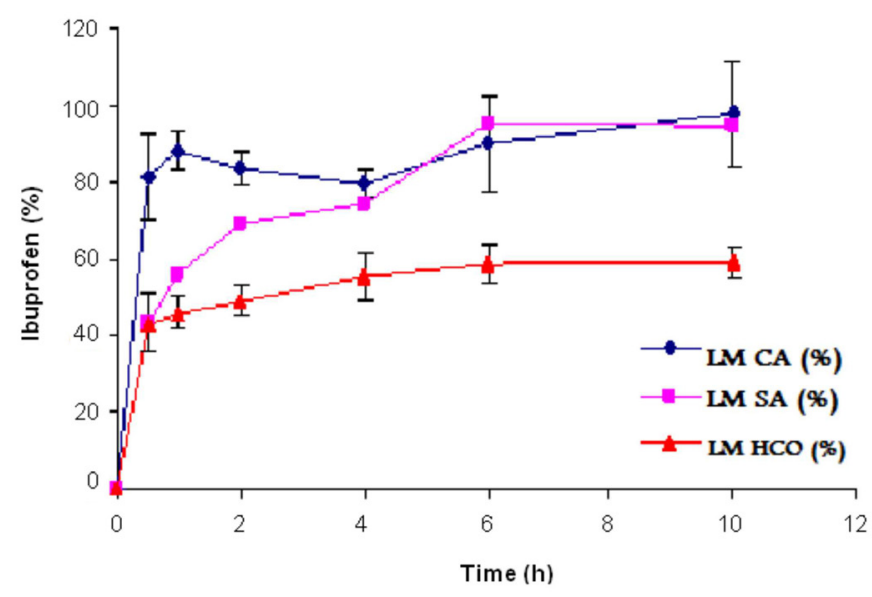

FIGURE 4 - Dissolution profiles of lipid microparticles of ibuprofen with different excipients (IB - Ibuprofen; LM CA- lipid microparticles of cetyl alcohol; LM SA - lipid microparticles of stearic acid; LM HCO - lipid microparticles of hydrogenated castor oil).

Physical mixtures were not evaluated in terms of dissolution rate because it was expected that this system would not allow the sustained release of drug.

The presence of lipids appears to affect the crystalline organization of ibuprofen. Solid dispersions and solid lipid microparticles were highly in amorphous form, in contrast to pure ibuprofen, which contributed to a decrease of dissolution/release of this drug. Besides, the sustained release profiles of solid dispersions and lipid microparticles can be attributed to the entrapment of drug in the lipid matrices.

\section{CONCLUSIONS}

The results of this work show that the type of excipients used to prepare solid dispersions and solid lipid microparticles influence the physical and mechanical properties, as well as the dissolution profiles of ibuprofen.

Solid dispersions of ibuprofen in stearic acid and hydrogenated castor oil showed better flow characteristics than pure ibuprofen and the respective physical mixtures. However, none of the solid lipid microparticles formulated with different excipients presented flow characteristics.

Sustained-release of ibuprofen was achieved with the preparation of solid dispersions and solid lipid microparticles using cetyl alcohol, stearic acid, and hydrogenated castor oil.

Due to their emulsifying properties, systems with cetyl alcohol presented higher percentages of ibuprofen released than stearic acid or hydrogenated castor oil. However, solid dispersions of ibuprofen in hydrogenated 
castor oil showed better flow characteristics and a more prolonged release of ibuprofen. These systems are easy to prepare and may lead to the avoidance of frequent drug administration.

\section{LIST OF ABBREVIATIONS}

IB - Ibuprofen

LM CA - Lipid Microparticles of Cetyl Alcohol

LM HCO - Lipid Microparticles of Hydrogenated Castor Oil

LM SA - Lipid Microparticles of Stearic Acid

PEG - Poly(ethylene glycol)

SD CA - Solid Dispersions of Cetyl Alcohol

SD HCO - Solid Dispersions of Hydrogenated Castor Oil

SD SA - Solid Dispersions of Stearic Acid

UV-VIS - Ultraviolet-Visible

\section{REFERENCES}

BRUNTON, L.L.; LAZO J.S.; PARKER K.L. (Eds.). Goodman \& Gilman's: as bases farmacológicas da terapêutica. 11.ed. Columbus: McGraw-Hill, 2007. p.1821.

CHIOU, W.L.; RIEGELMAN, S. Pharmaceutical applications of solid dispersion systems. Pharm. Acta Helv., v.60, n.9, p.1281-1301, 1971.

FORD, J.L.; RUBINSTEIN, M.H. Phase equilibria and dissolution rates of indomethacin-polyethylene glycol 6000 solid dispersions. Pharm. Acta Helv., v.53, n.11, p.327-332, 1978.

FORD, J.L. The current status of solid dispersions. Pharm. Acta Helv., v.61, n.3, p.69-88, 1986.

FREITAS, S.; MERKLE, H.P.; GANDER, B. Microencapsulation by solvent extraction/evaporation: reviewing the state of the art of microsphere preparation process technology. $J$. Control. Release., v.102, n.2, p.313-332, 2005.

GOUIN, S. Microencapsulation: industrial appraisal of existing technologies and trends. Trends Food Sci. Technol., v.15, n.7-8, p.330-347, 2004.

KANG, Y.; YIN, G.; OUYANG, P.; HUANG, Z.; YAO, Y.; LIAO, X.; CHEN, A.; PU, X. Preparation of PLLA/PLGA microparticles using solution enhanced dispersion by supercritical fluids (SEDS). J. Colloid Interface Sci., v.322, n. 1, p.87-94, 2008.
KUMAR, M.N.V. Nano and microparticles as controlled drug delivery devices. J. Pharm. Sci., v.3, n.2, p.234-258, 2000.

LACHMAN, L. Teoria e prática na indústria farmacêutica. 1.ed. Lisboa: Fundação Calouste Gulbenkian, 2001. p.737-738.

LIBERAL, J.P.M. Desenvolvimento e caracterização de comprimidos matriciais de dupla camada contendo Paracetamol. Porto, 2008. p.112. [Dissertation of Master Degree. Faculty of Pharmacy. University of Porto].

MAHAJAN, H.S.; GATTANI, S.G. Gellan gum based microparticles of metoclopromide hydrochloride for intranasal delevery: development and evaluation. Chem. Pharm. Bull., v.57, n.4, p.388-392, 2009.

NEWA M. Preparation and evaluation of immediate release ibuprofen solid dispersions using polyethylene glycol 4000. Biol. Pharm. Bull., v.31, n.5, p.939-945, 2008.

NEWA, M. Enhancement of solubility, dissolution and bioavailability of ibuprofen in solid dispersion systems. Chem. Pharm. Bull., v.56, n.4, p.569-574, 2008.

NEWA, M. Enhanced dissolution of ibuprofen using solid dispersion with poloxamer 407. Arch. Pharm. Res., v.31, n.1, p.1497-1507, 2008.

OSWALD, W.; GUIMARÃES, S. Terapêutica medicamentosa e suas bases farmacológicas. 4.ed. Porto: Porto Editora, 2001. p.1296.

PARK, Y.J.; KWON, R.; QUAN, Q.Z.; OH, D.H; KIM, J.O.; HWANG, M.R.; KOO, Y.B.; WOO, J.S.; YONG, C.S.; CHOI, H.G. Development of novel ibuprofen-loaded solid dispersion with improved bioavailability using aqueous solution. Arch. Pharm. Res., v.32, n.5, p.767-772, 2009.

ROWE, R.C.; SHESKEY, P.J.; WELLER, P.J. Handbook of pharmaceutical excipients. 4.ed. Washington: The Pharmaceutical Press, American Pharmaceutical Association, 2003. p.776.

SALOMEN, J.L.; DOELKER, E. Formulation of sustained release tablets. I. Inert matrices. Pharm. Acta Helv., v.55, n.7, p.174-182, 1980.

SHARMA, D.K.; JOSHI, S.B. Solubility Enhancement Strategies for Poorly Water-Soluble Drugs in Solid Dispersions: A Review. Asian J. Pharm., v.1, n.1, p.9-19, 2007. 
SOPPIMATH, K.S.; KULKARNI, A.R.; AMINABHAVI, T.M. Encapsulation of antihypertensive drugs in cellulose matrix microspheres: characterization and release of microspheres and tableted microspheres. J. Microencapsul., v.18, n.3, p.397-409, 2001.
YI, H.G.; CHI, M.H.; KIM, Yo; WOO, J.S.; PARK E. Formulation of a extended release tablet containing dexibruprofen. Arch. Pharm. Res., v.31, n.12, p.1637-1643, 2008.

Received for publication on $1^{\text {st }}$ November 2011 Accepted for publication on 27 $7^{\text {th }}$ April 2012 